Karol MAJEWSKI

Uniwersytet Ekonomiczny w Krakowie

Bernadetta ZAWILIŃSKA

Uniwersytet Ekonomiczny w Krakowie

\title{
DZIAłALNOŚĆ \\ ZESPOŁU PARKÓW KRAJOBRAZOWYCH WOJEWÓDZTWA MAŁOPOLSKIEGO W ZAKRESIE EDUKACJI I ROZWOJU TURYSTYKI ${ }^{1}$
}

\section{Wprowadzenie}

Istotnym czynnikiem wpływającym na skuteczność działań podejmowanych na rzecz ochrony przyrody i krajobrazu jest poziom świadomości oraz wrażliwości przyrodniczej wśród społeczeństwa. Owa zależność została ujęta m.in. w Ustawie o ochronie przyrody, która określa, iż „cele ochrony przyrody są realizowane przez: [...] prowadzenie działalności edukacyjnej, informacyjnej i promocyjnej w dziedzinie ochrony przyrody" (Ustawa, 2004, art. 3, par. 5). Parki krajobrazowe sa, obok parków narodowych, jedynymi wyszczególnionymi w Ustawie formami ochrony przyrody, które zaprojektowano nie tylko jako obszar chroniony, lecz także jako jednostkę organizacyjną mającą własne służby (Radecki, 2008, 2016). Zarówno parkom narodowym, jak i krajobrazowym oraz ich służbom przypisano cele i zadania z zakresu edukacji ekologicznej i turystyki. Trzeba jednak zauważyć, że w przypadku parków krajobrazowych cele te zostały wpisane już w samą definicję parku, który „obejmuje obszar chroniony ze względu na wartości przyrodnicze, historyczne i kulturowe oraz walory krajobrazowe w celu zachowania i popularyzacji tych wartości w warunkach zrównoważonego rozwoju" (Ustawa, 2004, art. 16, par. 1).

\footnotetext{
1 Publikacja została sfinansowana ze środków subwencji przyznanej Uniwersytetowi Ekonomicznemu w Krakowie, umowa nr 51/GGG/2020/POT.
} 
Popularyzacja w praktyce oznacza rozpowszechnianie wymienionych wartości poprzez edukację i działania na rzecz rozwoju turystyki.

Organizowanie działalności edukacyjnej, turystycznej i rekreacyjnej w parkach krajobrazowych należy do zadań dyrektora danego parku krajobrazowego lub zespołu parków krajobrazowych (Ustawa, 2004, art. 105, par. 4). Wśród głównych zadań Służby Parku Krajobrazowego wymieniono natomiast „prowadzenie edukacji przyrodniczej w szkołach i wśród miejscowego społeczeństwa, a także promowanie wartości przyrodniczych, historycznych, kulturowych i turystycznych parku krajobrazowego" (Ustawa, 2004, art. 107, par. 2). W planach ochrony parków krajobrazowych wskazywane są ponadto obszary udostępniane dla celów edukacyjnych, turystycznych i amatorskiego połowu ryb (Ustawa, 2004, art. 20, par. 4).

Działania z zakresu edukacji i turystyki należą więc - obok przedsięwzięć związanych z ochroną przyrody - do głównych prac podejmowanych przez parki krajobrazowe w Polsce. Działalność ta jest bardzo zróżnicowana pod względem oferowanej tematyki zajęć (m.in. z zakresu botaniki, zoologii, ekologii, geologii, historii, architektury, etnografii) i grup odbiorców (np. nauczyciele, przewodnicy, dzieci i młodzież, rodziny). Widoczna jest także duża różnorodność form pracy. Parki lub ich zespoły prowadzą ośrodki edukacyjne, zajęcia w szkołach, organizują pokazy filmów, wystawy, konkursy, zajęcia laboratoryjne i warsztaty (np. plastyczne, wikliniarskie, garncarskie, budowanie budek dla ptaków). Część parków dysponuje ośrodkami edukacyjnymi z zapleczem noclegowym, co umożliwia organizację „zielonych szkół” i innych wydarzeń wielodniowych. Ważne miejsce wśród realizowanych działań zajmują liczne zajęcia edukacyjne w terenie, wycieczki, a także rajdy, spływy kajakowe, gry terenowe, plenery malarskie i fotograficzne. Parki krajobrazowe organizują lub współorganizują także wiele imprez plenerowych, festynów i festiwali oraz konferencji i seminariów. Stwarzają studentom możliwość odbywania praktyk zawodowych i staży. Istotną część prac prowadzonych przez parki krajobrazowe stanowi rozwój zagospodarowania o charakterze edukacyjnym i turystyczno-rekreacyjnym (m.in. ścieżek dydaktycznych, tablic informacyjnych, wiat, ławek). Poza tym parki krajobrazowe prowadzą różnorodną działalność wydawnicza, informacyjną i promocyjną (Adamczewska, 2008; Chojnacka-Ożga, Ożga, Rutkiewicz, 2013; Fritzkowski, 2020; Rękas, 2004; Stachyrak, 1998; Wojciechowski, 2018; Zawilińska, 2007, 2010).

Prowadząc wyżej opisaną działalność, parki krajobrazowe współpracują z wieloma podmiotami, w szczególności z samorządami regionalnymi 
i lokalnymi, instytucjami naukowymi, Lasami Państwowymi, placówkami oświatowymi, organizacjami pozarządowymi, a także osobami fizycznymi (Fritzkowski, 2020; Łakomiec, 2002; Referowska-Chodak, 2018; Zawilińska, 2010). Wpływ parków krajobrazowych na rozwój turystyki oraz ich aktywność edukacyjna są przeważnie pozytywnie oceniane przez lokalne samorządy i mieszkańców (Kruk, 2014; Zawilińska, Hołuj, 2014). Trzeba jednak zauważyć, że dyrekcje parków krajobrazowych, a zwłaszcza ich zespołów, obejmują działalnością rozległe tereny (często położone w dużej odległości od siedziby), intensywnie (w stosunku do parków narodowych) zaludnione i zagospodarowane oraz zarządzane przez liczne podmioty. Ponadto zakres kompetencji powierzonych dyrektorom parków krajobrazowych jest nieduży, a zasoby kadrowe służb parków bardzo ograniczone. To wszystko sprawia, że pomimo intensywnych działań rozpoznawalność parków krajobrazowych jako instytucji jest w polskim społeczeństwie słaba (Schubert, 2008; Zimniewicz, 2005).

\section{Cel, metody badań i materiały źródłowe}

Celem pracy jest przedstawienie działalności Zespołu Parków Krajobrazowych Województwa Małopolskiego (ZPKWM) w zakresie edukacji i rozwoju turystyki oraz rozpoznanie, jak działalność ta jest postrzegana przez mieszkańców parków, turystów oraz miejscowe władze. Zakres przedmiotowy opracowania obejmuje wszystkie prace ZPKWM związane z prowadzoną działalnością edukacyjną oraz rozwojem turystyki, niezależnie od tego, czy działania te były prowadzone w granicach parków krajobrazowych czy poza nimi.

Pierwszą część pracy, dotyczącą działalności Zespołu, przygotowano przy użyciu metody analizy danych zastanych (desk research), pogłębionych wywiadów indywidualnych oraz badań terenowych (obserwacji uczestniczącej). Materiały źródłowe i dane statystyczne uzyskano w dyrekcji ZPKWM. Wywiady przeprowadzono w grudniu 2020 r. z Dyrektorem i z osobami odpowiedzialnymi w instytucji za działalność edukacyjną i rozwój turystyki. Obserwacje prowadzono biorąc udział w organizowanych przez jednostki Zespołu wydarzeniach edukacyjnych, w tym z wykorzystaniem mediów społecznościowych, oraz korzystając z infrastruktury edukacyjnej i turystyczno-rekreacyjnej przygotowanej przez parki.

Druga część pracy, dotycząca opinii mieszkańców, turystów oraz miejscowych władz, została opracowana na podstawie danych pozyskanych $\mathrm{z}$ badania przeprowadzonego przez Małopolskie Obserwatorium Rozwoju 
Regionalnego (Badanie..., 2019). Badanie zrealizowano w okresie letnim 2019 r. Prowadzono je na terenie wszystkich parków krajobrazowych w województwie metodą bezpośredniego indywidualnego wywiadu kwestionariuszowego. Zebrano opinie 2000 mieszkańców, 1077 turystów i 31 przedstawicieli władz gmin. W przypadku mieszkańców dobór próby miał charakter celowy, odpowiadał liczbie ludności zamieszkałej w poszczególnych parkach krajobrazowych oraz strukturze płci, wieku i wykształcenia mieszkańców. Wywiady przeprowadzono w 80 miejscowościach. Dobór próby badawczej spośród turystów odwiedzających parki krajobrazowe był proporcjonalny do powierzchni parków w trzech obszarach: Północnego Podkarpacia i wyżyn, Pogórza Karpackiego oraz Beskidów. W granicach parków badania prowadzono w miejscach o zróżnicowanych walorach turystycznych (przyrodniczych i kulturowych), wśród turystów uprawiających różne formy turystyki (wypoczynkowa, zdrowotna, poznawcza, kwalifikowaną i in.). Strukturę respondentów w grupach mieszkańców i turystów zaprezentowano na rysunku 1.

Dobierając próbę badawczą w celu rozpoznania opinii miejscowych samorządów, wytypowano gminy, w których parki krajobrazowe zajmują największy odsetek terenu (31 spośród 47 gmin). W każdej z gmin przeprowadzono wywiad z jedną osobą: wójtem lub burmistrzem, jego zastępcą bądź innym kompetentnym pracownikiem (głównie z osobami odpowiedzialnymi za rozwój turystyki i ochronę środowiska).
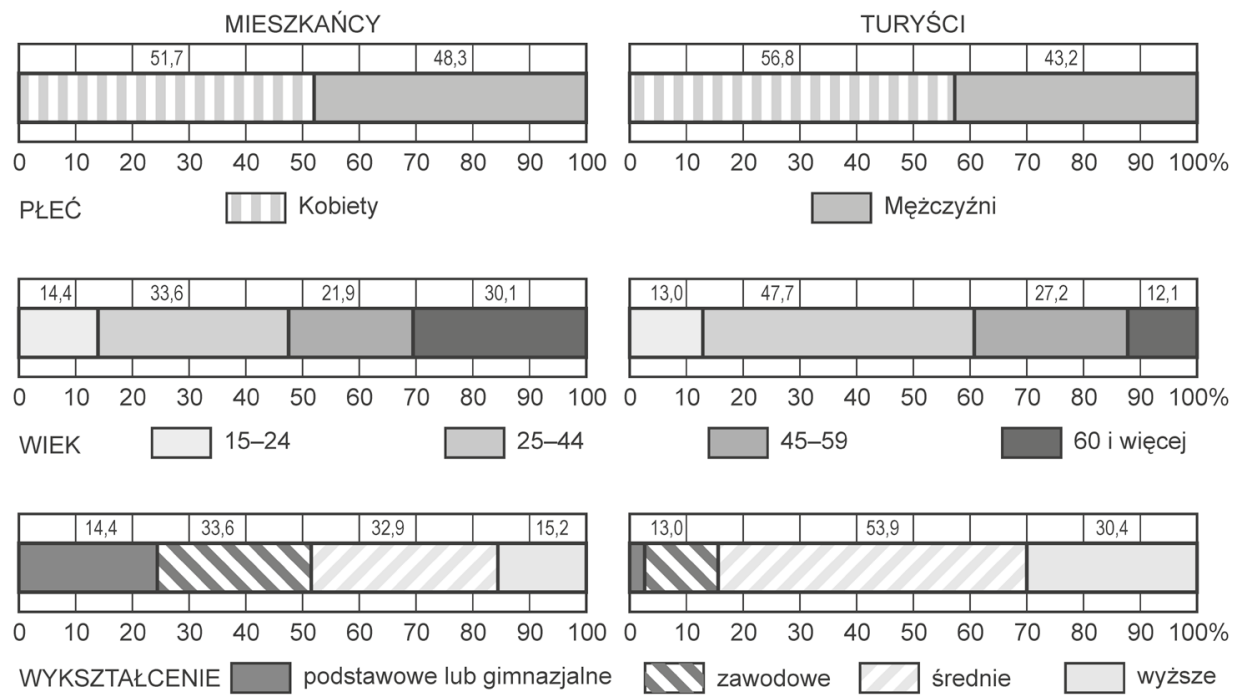

Rysunek. 1. Struktura respondentów Źródło: opracowanie własne na podstawie badań ankietowych 


\section{Zespół Parków Krajobrazowych Województwa Małopolskiego}

Nadzór nad parkami krajobrazowymi należy do kompetencji władz samorządowych szczebla wojewódzkiego. W celu usprawnienia zarządzania tymi obszarami Ustawa o ochronie przyrody umożliwia tworzenie zespołów parków (Ustawa, 2004, art. 106, par. 1). Obecnie większość parków krajobrazowych w Polsce została połączona w zespoły. W 2019 r. funkcjonowało 16 zespołów, kierujących 103 parkami krajobrazowymi, a 20 parków miało oddzielne dyrekcje (Ochrona środowiska 2019, 2019).

W województwie małopolskim funkcjonuje 11 parków krajobrazowych o łącznej powierzchni 178,3 tys. ha, co stanowi 11\% obszaru województwa (rys. 2), 6 parków krajobrazowych położonych jest na terenie

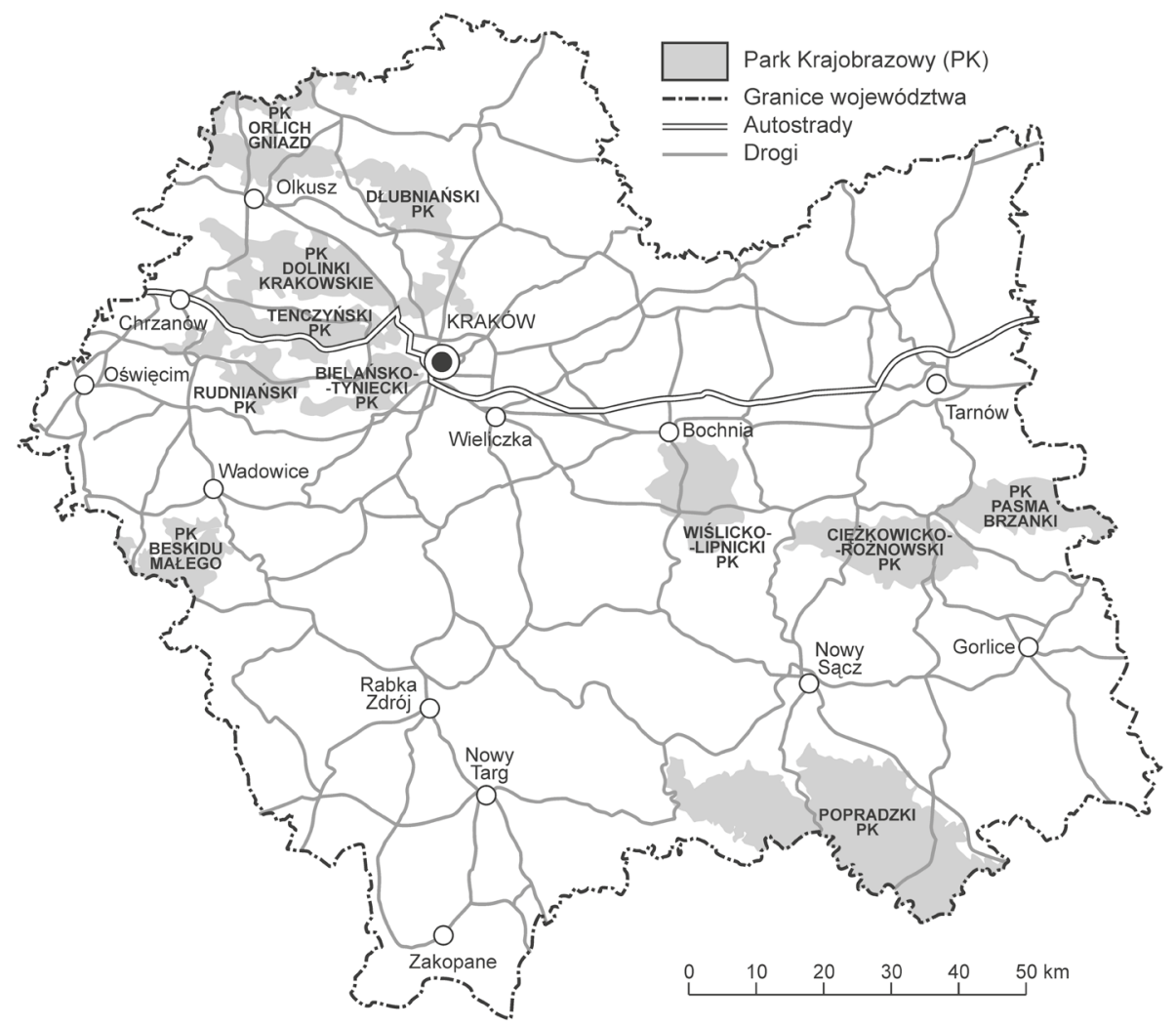

Rysunek 2. Parki krajobrazowe w województwie małopolskim

Źródło: opracowanie własne na podstawie danych: Generalna Dyrekcja Ochrony Środowiska (2020), Główny Urząd Geodezji i Kartografii (2020), OpenStreetMap (2020), ZPKWM (2020) 
wyżyn (głównie Krakowsko-Częstochowskiej) i kotlin podkarpackich (głównie Bramy Krakowskiej), a 5 w Karpatach (3 na Pogórzu Karpackim i $2 \mathrm{w}$ Beskidach). Parki krajobrazowe obejmują jedne z najcenniejszych przyrodniczo i najbardziej atrakcyjnych turystycznie terenów województwa (fot. 1).

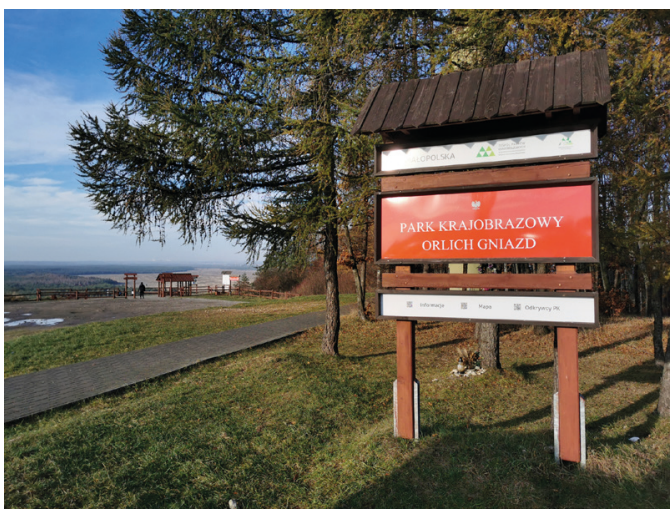

Fotografia 1. Tablica informacyjna Parku Krajobrazowego Orlich Gniazd przy punkcie widokowym na wzgórzu Czubatka Źródło: B. Zawilińska (2020)

Wszystkimi parkami krajobrazowymi kieruje Zespół Parków Krajobrazowych Województwa Małopolskiego. Jednostka została utworzona w 2009 r. w wyniku połączenia istniejących wcześniej podmiotów: Zespołu Jurajskich Parków Krajobrazowych (istniejącego od 1981 r.), Zespołu Parków Krajobrazowych Pogórza (funkcjonującego od 1997 r., pierwotnie w latach 1997-1998 pod nazwą: Zespół Parków Krajobrazowych Województwa Tarnowskiego) i Popradzkiego Parku Krajobrazowego (utworzonego w 1987 r.). Dyrekcja Zespołu ma siedzibę w Krakowie, natomiast trzy dawne jednostki organizacyjne funkcjonują jako oddziały, przy czym Oddział Stary Sącz (dawna dyrekcja Popradzkiego Parku Krajobrazowego), oprócz Popradzkiego Parku Krajobrazowego obejmuje także część Parku Krajobrazowego Beskidu Małego, położoną w województwie małopolskim.

Zgodnie ze Statutem ZPKWM w Krakowie Zespół jest „wojewódzką samorządową jednostką organizacyjną utworzoną w celu zapewnienia właściwej realizacji zadań z zakresu ochrony przyrody, walorów krajobrazowych, wartości historycznych i kulturowych oraz działalności edukacyjnych, w warunkach zrównoważonego rozwoju na obszarze parków krajobrazowych i obszarów chronionego krajobrazu [...] w granicach 
administracyjnych Województwa Małopolskiego" (Statut, 2015, par. 2). Obszarem działania Zespołu są więc obecnie nie tylko parki krajobrazowe, ale również obszary chronionego krajobrazu, co sprawia, że jednostka obejmuje swą działalnością około połowę terenów województwa.

W Statucie określono również trzy główne cele Zespołu, z których dwa dotyczą działalności edukacyjnej i rozwoju turystyki:

- popularyzacja i upowszechnianie wartości historyczno-kulturowych i przyrodniczo-krajobrazowych parków oraz obszarów chronionego krajobrazu, w warunkach zrównoważonego rozwoju, poprzez prowadzenie działalności dydaktycznej i edukacyjnej;

- zabezpieczenie warunków dla zgodnego z wymogami ekologii rozwoju turystyki i rekreacji parków i obszarów ochronionego krajobrazu oraz zagospodarowania przestrzennego parków.

W strukturze ZPKWM wydzielono sześć zespołów, w tym Zespół Edukacji, Turystyki i Rekreacji (ZETiR), liczący w 2019 r. ośmiu pracowników (łącznie w trzech oddziałach). Osoby te miały wykształcenie wyższe o zróżnicowanych profilach (biologia, geografia, leśnictwo, ochrona środowiska, technika rolnicza i leśna oraz turystyka i rekreacja). Zgodnie z Regulaminem organizacyjnym Zespołu Parków Krajobrazowych Województwa Małopolskiego (§ 17) do zadań ZETiR należy (Regulamin organizacyjny, 2018):

- organizacja działalności edukacyjnej, turystycznej oraz rekreacyjnej;

- prowadzenie edukacji przyrodniczej w szkołach i wśród miejscowego społeczeństwa, a także promowanie wartości przyrodniczych, historycznych, kulturowych i turystycznych parku krajobrazowego;

- współdziałanie w zakresie edukacji, turystyki i rekreacji z samorządami, organizacjami pozarządowymi i innymi podmiotami zainteresowanymi tą problematyką;

- popularyzacja walorów przyrody, środowiska, krajobrazu, wartości historycznych i kulturowych Parków Krajobrazowych i Obszarów Chronionego Krajobrazu;

- organizacja działalności Centrów Edukacji Przyrodniczej w Oddziałach;

- przygotowywanie materiałów edukacyjnych i promocyjnych: druków, folderów, ulotek itp.;

- prowadzenie strony internetowej i serwisów społecznościowych ZPKWM;

- tworzenie i realizowanie programów edukacyjnych;

- projektowanie, tworzenie i utrzymywanie infrastruktury ścieżek przyrodniczych;

- monitoring turystyczny. 


\section{Działania w zakresie edukacji i turystyki}

ZPKWM podejmuje wiele działań związanych z edukacją a zwłaszcza $z$ edukacją przyrodniczą społeczeństwa. Prace te, realizowane przez wszystkie trzy oddziały ZPKWM, skierowane są do osób w różnym wieku, o różnym poziomie wykształcenia i obejmują różnorakie formy edukacji: - zajęcia stacjonarne, prowadzone przede wszystkim w szkołach, a także przedszkolach oraz innych placówkach użyteczności publicznej;

- zajęcia terenowe na obszarach poszczególnych parków krajobrazowych;

- konkursy i wydarzenia okolicznościowe;

- edukacja poprzez Internet i działalność wydawnicza.

W 2019 r. Zespół zorganizował łącznie 500 zajęć edukacyjnych, w których uczestniczyło blisko 34 tys. osób. Zdecydowana większość zajęć miała formę prelekcji, pogadanek lub warsztatów realizowanych przez Zespół Edukacji, Turystyki i Rekreacji w szkołach lub innych placówkach oświatowych, wybranych placówkach użyteczności publicznej, a także w dwóch prowadzonych przez ZPKWM ośrodkach edukacji przyrodniczej: w Polichtach i Woli Kroguleckiej. Zajęcia tego typu stanowiły $72 \%$ ogółu zajęć edukacyjnych (stacjonarnych i terenowych), a łącznie

Zajęcia terenowe i zajęcia dla grup zorganizowanych

Zajęcia w sali edukacji przyrodniczej dla grup zorganizowanych

Zajęcia z edukatorem w szkołach

Spotkania edukacyjne poza szkołą (w Domu Kultury, Muzeum, Urzędzie Gminy)

Akcje, wydarzenia okolicznościowe, konferencje

Rajdy turystyczne, spacery przyrodnicze

- wydarzenia ogólnodostępne

Inne, np. stoiska edukacyjne na festynach, targach, piknikach itp.

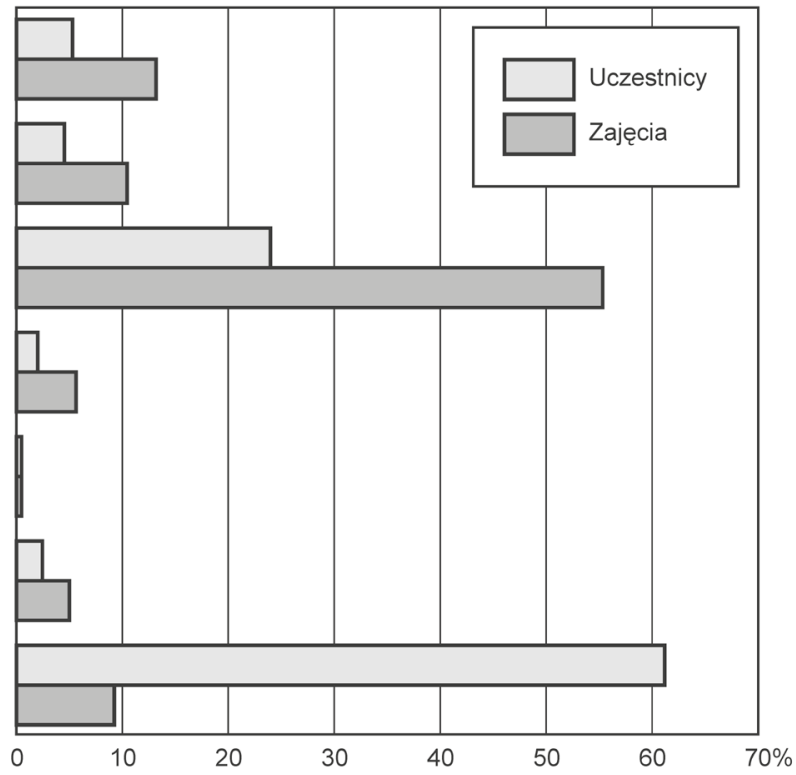

Rysunek 3. Struktura tematyczna zajęć edukacyjnych zorganizowanych przez ZPKWM w $2019 \mathrm{r}$. Źródło: opracowanie własne na podstawie danych ZPKWM (2020) 
wzięło w nich udział 10343 uczestników (rys. 3). Tematyka zajęć stacjonarnych dotyczyła nie tylko zagadnień przyrodniczych i kulturowych, ale też kwestii społecznych, m.in. związanych z zasadami i normami zachowania się na obszarach chronionych. Większość tego typu zajęć stacjonarnych $(78 \%)$ realizowana była w szkołach, wzięło w nich udział łącznie 8146 uczniów. W niektórych szkołach zajęcia prowadzone były cyklicznie przez cały rok szkolny w ramach współpracy ze szkolnymi kołami zainteresowań. $\mathrm{W}$ tym miejscu należy również zwrócić uwagę na działalność edukacyjną ZPKWM, kierowaną nie tylko do dzieci i młodzieży uczącej się, ale także do dorosłej części społeczeństwa, zwłaszcza osób zamieszkujących lub pracujących w granicach parków krajobrazowych, które mogą wywierać znaczący wpływ na funkcjonowanie środowiska przyrodniczego. W ramach tej aktywności Zespół organizował m.in. spotkania edukacyjne w urzędach gmin, szkolenia dla przewodników zrzeszonych w Studenckim Kole Przewodników Górskich w Krakowie oraz cykl szkoleń dla baców wypasających tereny cenne przyrodniczo.

Zajęcia terenowe, w tym wycieczki z edukatorem, rajdy turystyczne i spacery przyrodnicze, stanowiły 18\% zajęć zrealizowanych w 2019 r. Wśród nich organizowany był cykl ogólnodostępnych i darmowych wycieczek (pieszych, rowerowych oraz autokarowych), odbywających się co miesiąc w okresie od wiosny do jesieni w poszczególnych parkach krajobrazowych. Zajęcia w terenie realizowane są najczęściej na odpowiednio oznakowanych ścieżkach edukacyjnych ZPKWM, których łączna długość w granicach parków krajobrazowych wynosi ponad $270 \mathrm{~km}$ (fot. 2). Największa liczba ścieżek dydaktycznych (15) została wytyczona

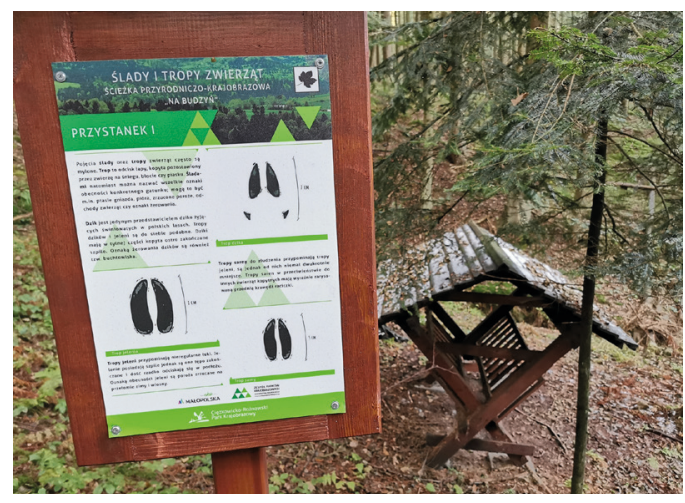

Fotografia 2. Przystanek ścieżki przyrodniczo-krajobrazowej „Na Budzyń" w Ciężkowicko-Rożnowskim Parku Krajobrazowym Źródło: B. Zawilińska (2020) 
w Popradzkim Parku Krajobrazowym, gdzie notuje się również największą ich sumaryczną długość w pojedynczym parku (tab. 1). Z kolei Park Krajobrazowy Beskidu Małego cechuje największa gęstość tychże ścieżek. W trzech parkach krajobrazowych: Dłubniańskim, Bielańsko-Tynieckim oraz Pasma Brzanki ścieżki edukacyjne nie zostały do tej pory utworzone.

Tabela 1. Długość i gęstość ścieżek dydaktycznych w parkach krajobrazowych województwa małopolskiego

\begin{tabular}{|r|l|c|c|}
\hline Lp. & \multicolumn{1}{|c|}{ Nazwa parku } & $\begin{array}{c}\text { Sumaryczna } \\
\text { długość ścieżek } \\
\text { dydaktycznych }(\mathrm{km})^{\mathrm{a}}\end{array}$ & $\begin{array}{c}\text { Gęstość ścieżek } \\
\text { dydaktycznych } \\
\left(\mathrm{m} / \mathrm{km}^{2}\right)\end{array}$ \\
\hline 1 & Popradzki Park Krajobrazowy & 121,87 & 228,15 \\
\hline 2 & Tenczyński Park Krajobrazowy & 45,91 & 336,14 \\
\hline 3 & Park Krajobrazowy Beskidu Małego & 42,23 & 466,09 \\
\hline 4 & $\begin{array}{l}\text { Ciężkowicko-Rożnowski } \\
\text { Park Krajobrazowy }\end{array}$ & 17,64 & 96,66 \\
\hline 5 & Park Krajobrazowy Orlich Gniazd & 15,70 & 122,22 \\
\hline 6 & $\begin{array}{l}\text { Park Krajobrazowy } \\
\text { Dolinki Krakowskie }\end{array}$ & 13,57 & 65,59 \\
\hline 7 & Rudniański Park Krajobrazowy & 9,00 & 154,78 \\
\hline 8 & $\begin{array}{l}\text { Wiśnicko-Lipnicki } \\
\text { Park Krajobrazowy }\end{array}$ & 4,90 & 34,43 \\
\hline 9 & Dłubniański Park Krajobrazowy & 0,00 & 0,00 \\
\hline 10 & $\begin{array}{l}\text { Bielańsko-Tyniecki } \\
\text { Park Krajobrazowy }\end{array}$ & 0,00 & 0,00 \\
\hline 11 & Park Krajobrazowy Pasma Brzanki & 0,00 & 0,00 \\
\hline
\end{tabular}

Objaśnienia: a w sumarycznej długości uwzględniono pełne długości ścieżek dydaktycznych wraz z ich odcinkami wykraczającymi poza granice parków.

Źródło: opracowanie własne na podstawie danych z Geoportalu ZPKWM (2020).

Tematyka ścieżek dydaktycznych ZPKWM jest bardzo zróżnicowana. Utworzone zostały zarówno ścieżki wielotematyczne (łączące m.in. treści przyrodnicze, kulturowe i historyczne), jak również monotematyczne (np. geologiczne, botaniczne lub ornitologiczne). Przystanki części ścieżek oznakowano kodami QR, które pozwalają turystom, korzystającym $\mathrm{z}$ własnych urządzeń mobilnych z dostępem do Internetu, na samodzielne czerpanie wiedzy o walorach przyrodniczych i kulturowych parków. Do ścieżek opracowano także przewodniki, dostępne $\mathrm{w}$ formie papierowej lub elektronicznej. 
Zdecydowana większość zajęć edukacyjnych przeprowadzona została w 2019 r. dla grup zorganizowanych (85\%), w zajęciach tych (zarówno w formie stacjonarnej, jak i terenowej) wzięło udział łącznie 12116 osób, wśród których największy odsetek (66\%) stanowiły dzieci ze szkół podstawowych w wieku od 7 do 14 lat (rys. 4). Średnia wielkość grup uczestniczących w zajęciach edukacyjnych to 28 osób, a średni czas trwania zajęć nie przekraczał 1 h 37 min. Większość spotkań (69\%) miała charakter stacjonarny, natomiast tyko $16 \%$ zajęć realizowanych było $\mathrm{w}$ całości w terenie. Zajęcia edukacyjne dla grup zorganizowanych prowadzone były dla szkół zlokalizowanych w 46 gminach województwa małopolskiego, w tym w 26 gminach z parkami krajobrazowymi w ich granicach (rys. 5). Zatem w 21 gminach związanych administracyjnie z parkami krajobrazowymi nie współpracowano ze szkołami w zakresie prowadzenia zajęć edukacyjnych (zajęć nie realizowano m.in. w żadnej ze szkół z 5 gmin Parku Krajobrazowego Beskidu Małego), natomiast prowadzono edukację w szkołach gmin poza parkami krajobrazowymi (głównie położonych w pobliżu siedzib Oddziałów ZPKWM, w tym na obszarach chronionego krajobrazu).

Z wywiadów przeprowadzonych z pracownikami Zespołu Edukacji, Turystyki i Rekreacji ZPKWM wynika, że placówki oświatowe z terenu parków krajobrazowych nie korzystają z oferty edukacyjnej Zespołu

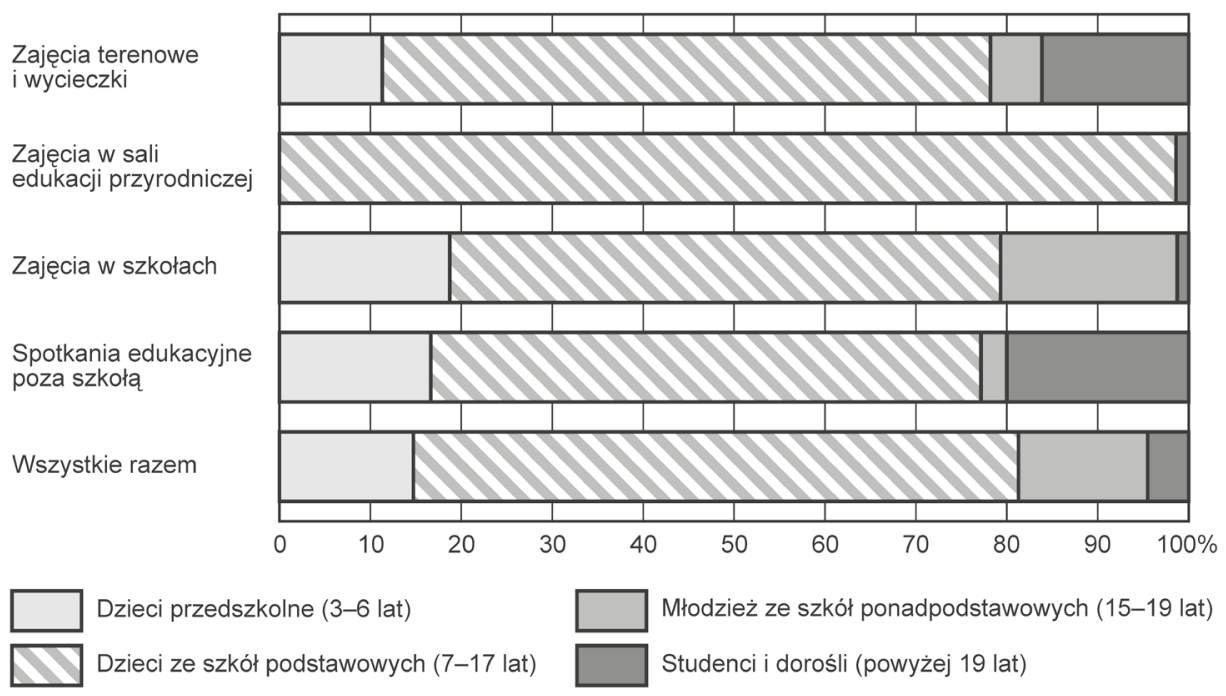

Rysunek 4. Struktura uczestników zajęć edukacyjnych dla grup zorganizowanych przeprowadzonych przez ZPKWM w 2019 r. Zródło: opracowanie własne na podstawie danych ZPKWM (2020) 


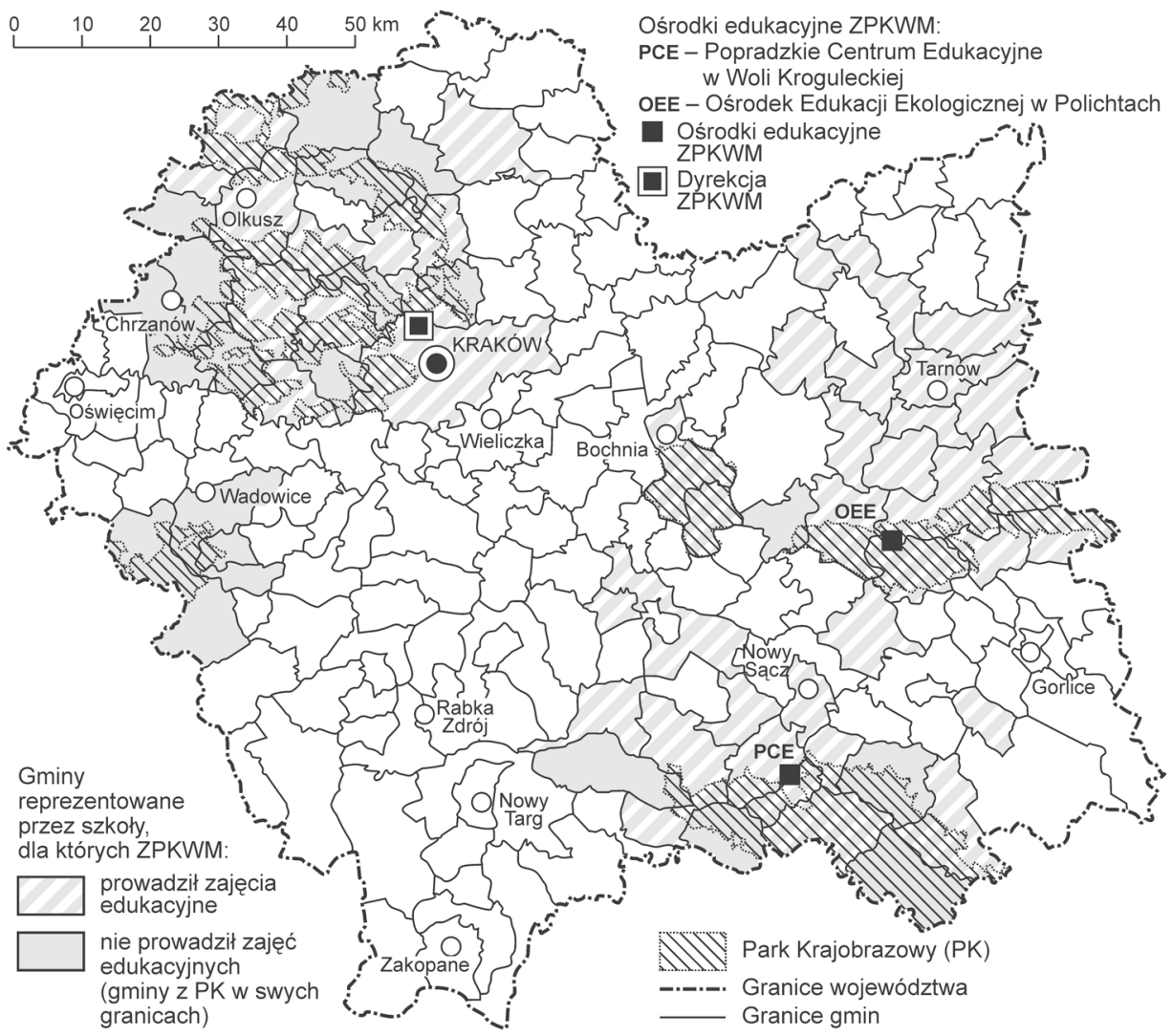

Rysunek 5. Gminy województwa małopolskiego ze szkołami,

które uczestniczyły w zajęciach edukacyjnych organizowanych przez ZPKWM w 2019 r. Źródło: opracowanie własne na podstawie danych:

Generalna Dyrekcja Ochrony Środowiska (2020), Główny Urząd Geodezji i Kartografii (2020), ZPKWM (2020)

z różnych powodów. W przypadku szkół zlokalizowanych w granicach Parku Krajobrazowego Beskidu Małego za jedną z głównych przyczyn takiego stanu rzeczy należy uznać odległość, jaka dzieli siedzibę Oddziału Stary Sącz i Popradzkie Centrum Edukacyjne (odpowiedzialne za działalność edukacyjną również w PKBM) od granic tego parku. Owa odległość znacznie utrudnia nawiązanie ścisłej współpracy pomiędzy Oddziałem a szkołami, tym bardziej że szkoły te mogą korzystać z oferty edukacyjnej Zespołu Parków Krajobrazowych Województwa Śląskiego (obejmującego m.in. część PKBM zlokalizowaną w województwie śląskim) bądź Babiogórskiego Parku Narodowego, których ośrodki edukacyjne zlokalizowane są zdecydowanie bliżej. ZPKWM podjął kroki, aby ożywić tę współpracę, 
delegując w 2020 r. jednego z pracowników ZETiR Oddziału Stary Sącz do pracy przy dyrekcji ZPKWM w Krakowie, skąd prowadzenie działalności edukacyjnej dla placówek oświatowych w PKBM byłoby bardziej dogodne. Na wymierne efekty tych zmian trzeba jednak poczekać do wznowienia działalności edukacyjnej Zespołu w tradycyjnej formie po opanowaniu pandemii koronawirusa. Brak współpracy na polu edukacji pomiędzy ZPKWM a szkołami z takich gmin, jak Ochotnica Dolna czy Szczawnica należy wiązać przede wszystkim z lokalizacją tych placówek w bliskim sąsiedztwie parków narodowych (Gorczańskiego i Pienińskiego), z których oferty edukacyjnej niektóre szkoły korzystają w pierwszej kolejności. Nawiązanie relacji pomiędzy szkołami a ZPKWM zależy ostatecznie nie tylko od prac Zespołu na rzecz promocji działalności edukacyjnej. Równie istotne są także chęci podjęcia takiej współpracy wyrażane przez dyrekcję bądź nauczycieli poszczególnych placówek oświatowych i ich zaangażowanie na rzecz zapewnienia uczniom możliwości uczestnictwa w różnorodnych formach zajęć edukacyjnych, służących poszerzaniu wiedzy i rozwijaniu wrażliwości przyrodniczej.

Ważnymi miejscami dla prowadzenia działalności edukacyjnej (przede wszystkim dla grup zorganizowanych), są dwa ośrodki edukacyjne, kierowane przez oddziały: Stary Sącz i Tarnów. Pierwszy z nich to Popradzkie Centrum Edukacyjne działające przy siedzibie Oddziału Stary Sącz w Woli Kroguleckiej, a drugi to Ośrodek Edukacji Ekologicznej w Polichtach na terenie Ciężkowicko-Rożnowskiego Parku Krajobrazowego. Oba ośrodki dysponują salami dydaktycznymi, które wyposażone są w liczne pomoce: tablice, gabloty ze zbiorami zielnikowymi, entomologicznymi czy geologicznymi, modele, plansze oraz gry edukacyjne. Na wyposażeniu ośrodków znajduje się ponadto sprzęt multimedialny wspomagający proces dydaktyczny. W pobliżu obu ośrodków zostały wytyczone ścieżki edukacyjne, pozwalające na realizację zajęć terenowych. W przypadku Popradzkiego Centrum Edukacyjnego należy również wspomnieć o dodatkowym obiekcie edukacyjnym, jakim jest arboretum, w którym zgromadzono liczne gatunki drzew oraz krzewów typowych dla naturalnych siedlisk Popradzkiego Parku Krajobrazowego. W wyniku wywiadów przeprowadzonych z Dyrektorem i pracownikami Zespołu Edukacji, Turystyki i Rekreacji ZPKWM uzyskano informacje o planowanym otwarciu nowych ośrodków edukacyjnych w Krakowie, Rytrze oraz Jastrzębi, w ramach tworzenia sieci Centrów Edukacji Przyrodniczej EkoMałopolska. Ośrodek krakowski służyć ma przede wszystkim organizacji warsztatów i wystaw tematycznych. Natomiast do pozostałych dwóch ośrodków przeniesione zostaną funkcje 
ośrodków edukacyjnych z dotychczasowych lokalizacji w Woli Kroguleckiej oraz Polichtach. Dodatkowo ośrodek edukacyjny w Jastrzębi ma być wyposażony w zaplecze noclegowe, pozwalające na organizację kilkudniowych zajęć edukacyjnych dla uczniów w formie np. zielonych szkół. Z kolei w ośrodku w Rytrze ma funkcjonować sala wystawiennicza oraz punkt informacji turystycznej.

Przedstawione powyżej formy działalności edukacyjnej są kluczowe w aspekcie liczby wydarzeń oraz zakresu przekazywanych treści, natomiast największą liczbę uczestników gromadzą otwarte inicjatywy o masowym charakterze (festyny, pikniki, targi), w których ZPKWM bierze udział jako organizator, współorganizator lub uczestnik. W 2019 r. stoiska edukacyjne Zespołu podczas takich wydarzeń odwiedziło ponad 20 tys. osób (61\% ogółu biorących udział w zajęciach edukacyjnych w tym roku, niezależnie od ich formy). Jako przykład podać można organizowane co roku pikniki rodzinne "Odkrywców małopolskich parków krajobrazowych", odbywające się w Parku Jordana w Krakowie oraz w pozostałych Oddziałach ZPKWM. Latem 2020 r., gdy organizowanie imprez masowych zostało ograniczone $\mathrm{w}$ związku z pandemią koronawirusa, ZPKWM zainicjował funkcjonowanie weekendowych stanowisk informacyjno-edukacyjnych w poszczególnych parkach krajobrazowych w ramach akcji „Lato na Jurze” i „Lato na Pogórzu”.

Kierując ofertę edukacyjną do szerokiego grona odbiorców, ZPKWM rozwija także program edukacyjny o nazwie „Odkrywcy Parków Krajobrazowych", któremu przyświeca cel aktywizowania dzieci, młodzieży i rodzin z dziećmi do poznawania i odkrywania małopolskich parków krajobrazowych indywidualnie z wykorzystaniem materiałów edukacyjnych przygotowanych przez Zespół. Celowi takiemu służą również gry terenowe, przygotowane przez Zespół w formie "questów", łączące elementy zabawy oraz nauki. Inicjatywami skierowanymi do szerokiego kręgu odbiorców są także konkursy. W 2019 r. ZPKWM zorganizował dwa konkursy wiedzy o parkach krajobrazowych oraz jeden konkurs plastyczny, w których łącznie udział wzięło ponad 1400 uczestników, reprezentujących 82 szkoły lub innych partnerów. Zespół współorganizował także osiem kolejnych konkursów o tematyce przyrodniczej w tym konkursy z wiedzy, plastyczne i techniczne, literackie oraz fotograficzne. W 2020 r. ZPKWM zorganizował konkurs internetowy „Parki Krajobrazowe Polski" o zasięgu ogólnopolskim, który przyciągnął 902 uczestników reprezentujących 216 szkół z terenu wszystkich województw. Wśród innych wydarzeń kierowanych do ogółu społeczeństwa, które organizuje lub współorganizuje ZPKWM, należy wymienić również ogólnodostępne 
konferencje poświęcone ochronie środowiska oraz akcje sprzątania parków krajobrazowych.

Wśród prac na rzecz edukacji i rozwoju turystyki prowadzonych przez małopolskie parki krajobrazowe nie można pominąć działalności wydawniczej, w ramach której opracowywane są m.in. mapy turystyczne, przewodniki po poszczególnych parkach krajobrazowych oraz foldery i ulotki informacyjne, zawierające gotowe pomysły na wycieczki bądź prezentujące największe atrakcje poszczególnych parków. ZPKWM wydaje również publikacje naukowe bądź popularno-naukowe o szerokiej tematyce dotykającej nie tylko zagadnień przyrodniczych ale i kulturowych bądź historycznych. Kolejnymi pozycjami w ofercie wydawniczej ZPKWM są spacerowniki z kartami pracy, wydawane przede wszystkim z myślą o uczestnikach programu „Odkrywcy Parków Krajobrazowych” oraz karty wypraw dla uczestników poszczególnych "questów”.

Należy zwrócić uwagę na to, że zdecydowana większość wymienionych wcześniej publikacji wydawanych przez ZPKWM jest dostępna za darmo na stronie internetowej Zespołu. Edukacyjny wymiar serwisu internetowego ZPKWM wyraża się również poprzez zamieszczone na nim kompendium informacji na temat przyrody, walorów kulturowych oraz turystyki w poszczególnych parkach krajobrazowych. Na stronie internetowej Zespołu widnieją informacje na temat aktualnie organizowanych konkursów i projektów edukacyjnych (ZPKWM, 2020).

W serwisie internetowym ZPKWM zamieszczono również obszerny wykaz proponowanych tematów prac dyplomowych z zakresu przyrody ożywionej i nieożywionej, krajobrazu, dziedzictwa kulturowego oraz turystyki proponowanych do realizacji przez studentów na terenie parków krajobrazowych. Zespół w ramach rozwijania współpracy z uczelniami wyższymi umożliwia odbycie praktyk studenckich, z których najczęściej korzystają studenci kierunków przyrodniczych bądź związanych z turystyką i rekreacją.

ZPKWM rozwija ponadto w Internecie własny Geoportal tworzący Publiczny System Informacji Przestrzennej, który pełni funkcję informacyjną oraz edukacyjną. Dzięki Geoportalowi użytkownicy mogą czerpać informacje o walorach przyrodniczych, krajobrazowych i kulturowych, zagospodarowaniu terenu, podejmowanych działaniach ochronnych i zagrożeniach $\mathrm{w}$ parkach krajobrazowych w ujęciu przestrzennym. Stanowi on również cenne źródło informacji na temat lokalizacji głównych atrakcji turystycznych, obiektów bazy noclegowej, parkingów oraz przebiegu szlaków turystycznych i ścieżek edukacyjnych, co czyni go przydatnym narzędziem do planowania turystyki na terenie parków. 
Istotną platformą prowadzenia działalności edukacyjnej przez ZPKWM są również internetowe media społecznościowe, w tym przede wszystkim portal Facebook. Na facebookowej stronie ZPKWM umieszczane są posty m.in. o aktualnie prowadzonych projektach, konkursach czy innych wydarzeniach edukacyjno-promocyjnych. Regularnie publikowane są tam również ciekawostki przyrodnicze bądź historyczne dotyczące poszczególnych parków krajobrazowych, informacje o bieżących pracach i inwestycjach na terenie ZPKWM, a także relacje fotograficzne lub filmowe z obserwacji świata przyrody dokonywanych przez pracowników Zespołu na terenie parków. Strona ZPKWM ma 7765 polubień i obserwuje ją 8427 użytkowników (stan na 15.01.2021 r.), co czyni ją zdecydowanie najbardziej popularną spośród wszystkich stron zespołów parków krajobrazowych na portalu Facebook w Polsce. Według statystyk posty zamieszczone przez ZPKWM w 2019 r. dotarły do prawie 113 tys. odbiorców. Zespół prowadzi ponadto swój kanał na portalu YouTube, na którym regularnie zamieszczane są materiały filmowe o charakterze edukacyjnym. Do stycznia 2021 r. ZPKWM opublikował 51 filmów, które łącznie mają 14800 wyświetleń (stan na 15.01.2021 r.).

\section{Działalność parków krajobrazowych w zakresie edukacji i turystyki z perspektywy mieszkańców, turystów oraz władz lokalnych}

Przechodząc do analizy postrzegania działalności edukacyjnej parków krajobrazowych oraz ich wpływu na rozwój turystyki, warto zwrócić uwagę na bardzo wysokie poparcie respondentów dla parków krajobrazowych. Niemal wszyscy turyści i mieszkańcy (odpowiednio 98,4\% i 92,4\%) uznali, że funkcjonowanie parku, do którego przyjechali lub w którym mieszkają jest potrzebne. Nasuwa się jednak przypuszczenie, iż w przypadku części turystów wyrażone poparcie należy interpretować jako generalną aprobatę dla ochrony przyrody lub walorów krajobrazowych, a nie dla konkretnego obszaru chronionego, gdyż ponad połowa pytanych, przyjeżdżając na dany teren, nie wiedziała, że znajduje się w parku krajobrazowym, a tylko dwie na pięć osób potrafiły poprawnie podać jego nazwę. Mieszkańcy natomiast byli świadomi, że mieszkają w parku krajobrazowym, lecz część z nich (28\%) także nie znała jego nazwy.

Zarówno w grupie mieszkańców, jak i turystów ponad połowa pytanych nie korzystała nigdy z żadnych źródeł wiedzy na temat parków 
krajobrazowych. Osoby, które szukały informacji o parkach, najczęściej czerpały je z Internetu (przy czym jedynie nieliczni korzystali z serwisów prowadzonych przez ZPKWM) oraz tablic informacyjnych umieszczonych na terenie parku krajobrazowego (rys. 6). Respondenci, którzy poszukiwali wcześniej wiedzy na temat parku, najczęściej dobrze oceniali dostępność informacji (w obydwu grupach badanych średnia ocen w skali od 1 do 5 wyniosła 4,0) - rys. 7 . Pozytywne oceny dostępności informacji przeważały we wszystkich parkach krajobrazowych.

Zespół Parków Krajobrazowych Województwa Małopolskiego jako instytucja okazał się bardzo słabo rozpoznawalny przez obydwie grupy respondentów, 94\% mieszkańców i 97\% turystów w ogóle o nim nie słyszało lub nie wiedziało czym się zajmuje. Zaledwie 2,4\% mieszkańców przyznało, że oni sami bądź członkowie ich najbliższych rodzin wzięli udział w wydarzeniach lub spotkaniach zorganizowanych przez parki krajobrazowe, natomiast kolejne 16,6\% słyszało o takich wydarzeniach. Co dwudziesty mieszkaniec był w stanie podać przykład aktywności parków krajobrazowych w miejscu swojego zamieszkania - najczęściej były to działania związane z oznakowaniem turystycznym, budową elementów małej infrastruktury (zwłaszcza tablic informacyjnych) i promocją regionu.

Zajęcia edukacyjne

i spotkania z przedstawicielami

Tablice informacyjne umieszczone na terenie parku

Publikacje książkowe i artykuły

Inne źródła internetowe

Media społecznościowe (np. oficjalny fanpage)

Oficjalna strona ZPKWM

Nie korzystali z żadnych źródeł wiedzy

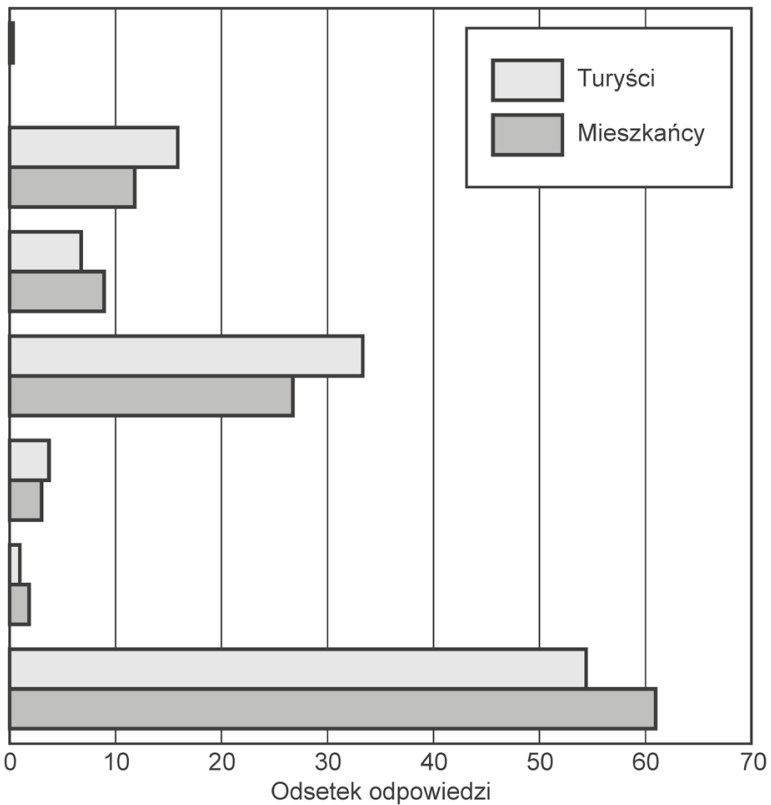

Rysunek 6. Źródła, z których mieszkańcy i turyści czerpali wiedzę na temat parku krajobrazowego Źródło: opracowanie własne na podstawie badań ankietowych 


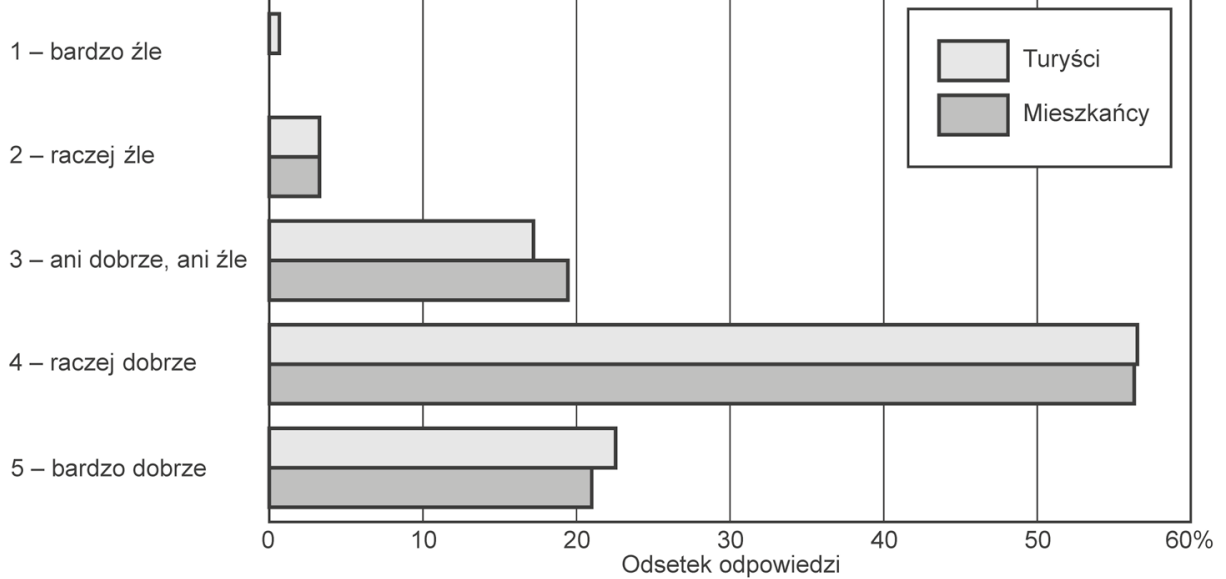

Rysunek 7. Ocena dostępności informacji na temat parku krajobrazowego Źródło: opracowanie własne na podstawie badań ankietowych

Z badań wynika, że obydwie grupy respondentów wykazały duże zainteresowanie udziałem $\mathrm{w}$ wydarzeniach edukacyjnych organizowanych przez parki krajobrazowe. Gotowość uczestniczenia w różnych formach edukacji wyraziło 58,7\% turystów i 49\% mieszkańców, natomiast 33,1\% turystów i 39,2\% mieszkańców wskazało jedną formę. Najbardziej atrakcyjne okazały się wycieczki krajoznawcze i przyrodnicze, w których chciałaby wziąć udział $1 / 2$ mieszkańców i $3 / 4$ turystów (rys. 8). Niemal co czwarty mieszkaniec i co trzeci turysta deklarował gotowość włączenia się w działania na rzecz ochrony przyrody i krajobrazu lub promowania różnorodności biologicznej. Oświadczenia te wskazują na duże możliwości rozwoju wolontariatu w parkach krajobrazowych.

W celu identyfikacji grup respondentów, którzy wykazują największe zainteresowanie udziałem $\mathrm{w}$ wydarzeniach edukacyjnych i włączeniem się w działania na rzecz parków, oraz znalezienia zależności pomiędzy zainteresowaniem tymi zajęciami a określonymi cechami respondentów, skonstruowano tabele wielodzielcze oraz zbadano relacje pomiędzy zmiennymi, wykorzystując test chi-kwadrat $\left(\chi^{2}\right)$ i współczynnik kontyngencji V-Cramera (V). Test chi-kwadrat wykazał istotne statystycznie związki pomiędzy zainteresowaniem udziałem $w$ wydarzeniach edukacyjnych oraz gotowością do włączenia się w działania na rzecz parków krajobrazowych z wiekiem i wykształceniem respondentów, a w przypadku mieszkańców także z wykazywaną przez nich aktywnością turystyczną lub rekreacyjną na terenach parków. Korelacje tych cech, mierzone współczynnikiem V-Cramera, nie były jednak silne. 


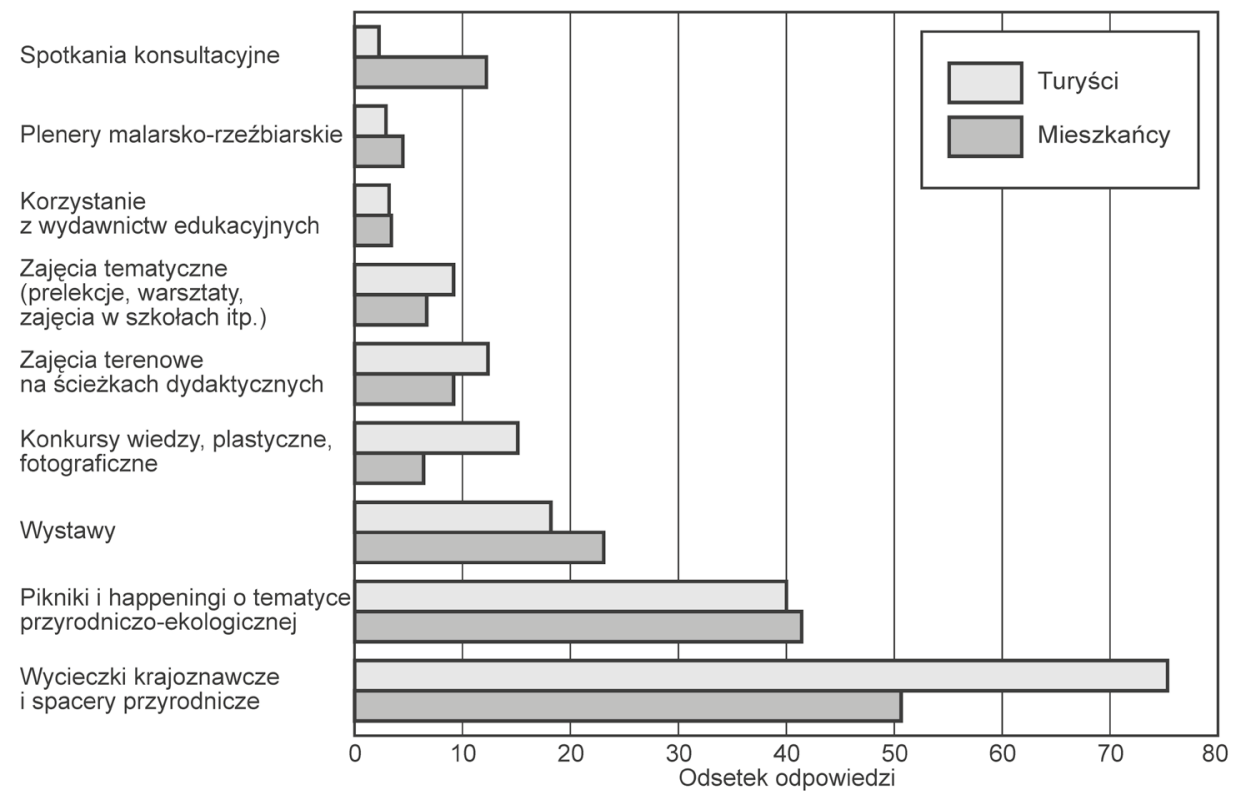

Rysunek 8. Deklaracje zainteresowania udziałem w formach edukacji

organizowanych przez parki krajobrazowe

Źródło: opracowanie własne na podstawie badań ankietowych

Najsilniejsze związki wystąpiły pomiędzy stopniem aktywności turystyczno-rekreacyjnej mieszkańców ${ }^{2}$, a ich gotowością do wzięcia udziału w inicjatywach edukacyjnych parków $(\mathrm{V}=0,38)$ i włączenia się w działania na rzecz parków $(\mathrm{V}=0,20)$. Bardziej aktywni turystycznie mieszkańcy częściej wyrażali zainteresowanie wydarzeniami edukacyjnymi i włączeniem się w działania na rzecz parków. Analizując tabele kontyngencji, zauważyć można, że grupami respondentów najbardziej zainteresowanymi ofertą edukacyjną parków krajobrazowych są mieszkańcy młodzi - w wieku od 15 do 24 lat (90,6\% zadeklarowało udział w co najmniej jednej formie edukacji), z wyższym wykształceniem $(92,4 \%)$ i uprawiający różne formy aktywności turystyczno-rekreacyjne $(96,4 \%)$. Wśród turystów zainteresowanie ofertą edukacyjną najczęściej wyrażały osoby z dwóch średnich grup wiekowych: 25-44 lata (92,6\%) i 45-59 lat $(92,8 \%)$, z wyższym lub średnim wykształceniem $(92,4 \%)$.

2 Pod względem aktywności turystycznej lub rekreacyjnej mieszkańców podzielono na trzy grupy: 1. osoby, które nie uprawiają żadnych form aktywności na terenie parku krajobrazowego; 2 . osoby, które wymieniły jedną formę aktywności (najczęściej spacery lub wycieczki piesze); 3. osoby, które wymieniły więcej niż jedną formę (m.in. wycieczki rowerowe, przejażdżki konne, bieganie, spływy kajakowe). 
Te same grupy respondentów najczęściej deklarowały włączenie się w działania na rzecz danego parku krajobrazowego: osoby z najmłodszej z badanych grup wiekowych (38,2\% mieszkańców i 40\% turystów), z wyższym wykształceniem (odpowiednio 31,3\% i 36,4\%) i w przypadku mieszkańców osoby uprawiające różne formy aktywności turystyczno-rekreacyjnej $(36,4 \%)$.

Trzecią grupą respondentów, oprócz mieszkańców i turystów, byli przedstawiciele lokalnych władz. Rozmówcy z tej grupy również wyrażali poparcie dla funkcjonowania parków krajobrazowych, a korzyści dla gmin wiązali głównie z rozwojem turystyki. Średnia ocena wpływu parków na wzrost liczby turystów w gminie w skali od 1 do 5 wyniosła 4,3. Respondenci przeważnie dobrze $(43,8 \%)$ lub bardzo dobrze $(34,4 \%)$ oceniali współpracę i komunikację gminy z ZPKWM. Tylko w jednym przypadku nie współdziałano dotychczas z Zespołem, stałą współpracę prowadziło 34,4\% badanych gmin, a współpracę okazjonalną 59,4\%. Wśród wspólnych działań w zakresie edukacji i turystyki najczęściej wskazywano organizację spotkań edukacyjnych oraz festynów i innych imprez (rys. 9). Poza wymienionymi formami aktywności współpraca władz lokalnych z ZPKWM związana jest $\mathrm{z}$ wymaganymi prawnie procedurami opiniowania dokumentów dotyczących zagospodarowania przestrzennego gmin oraz planów ochrony parków krajobrazowych (w których znajdują się również zapisy dotyczące rozwoju turystyki i działalności edukacyjnej).

Respondentów poproszono także o ocenę dotychczasowych prac ZPKWM w zakresie promocji i rozwoju turystyki oraz działań informa-

Organizowanie wycieczek krajoznawczych

Opracowywanie publikacji

Działania informacyjne i promocyjne parku

krajobrazowego i gminy

Budowa i renowacja infrastruktury na terenie parku krajobrazowego

Organizacja spotkań edukacyjnych, festynów i innych imprez

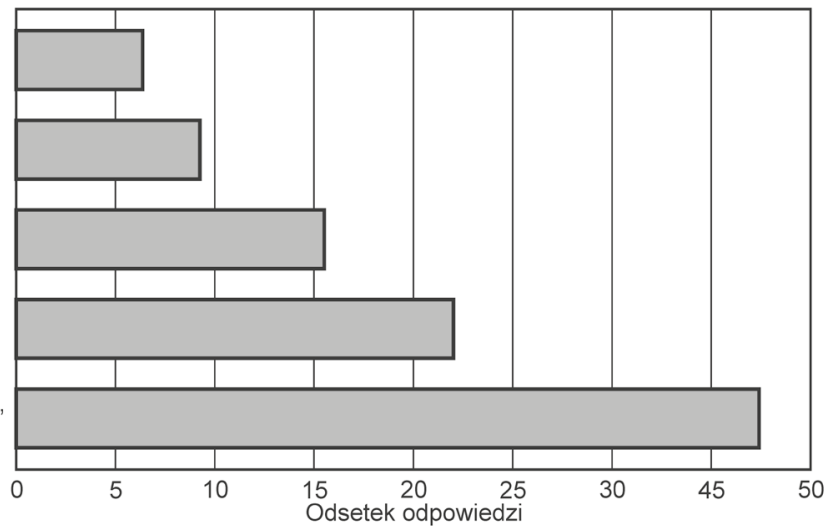

Rysunek 9. Wspólne działania gmin i parków krajobrazowych w zakresie edukacji i turystyki

Źródło: opracowanie własne na podstawie badań ankietowych 
cyjnych i edukacyjnych prowadzonych na terenie gminy. W znacznej części gmin działania takie nie były prowadzone przez Zespół lub respondenci nie mieli zdania na ich temat. Częściej dostrzegano i pozytywnie oceniano działalność informacyjną i edukacyjną parków niż zaangażowanie w kampanie promocyjne i rozwój turystyki (rys. 10).

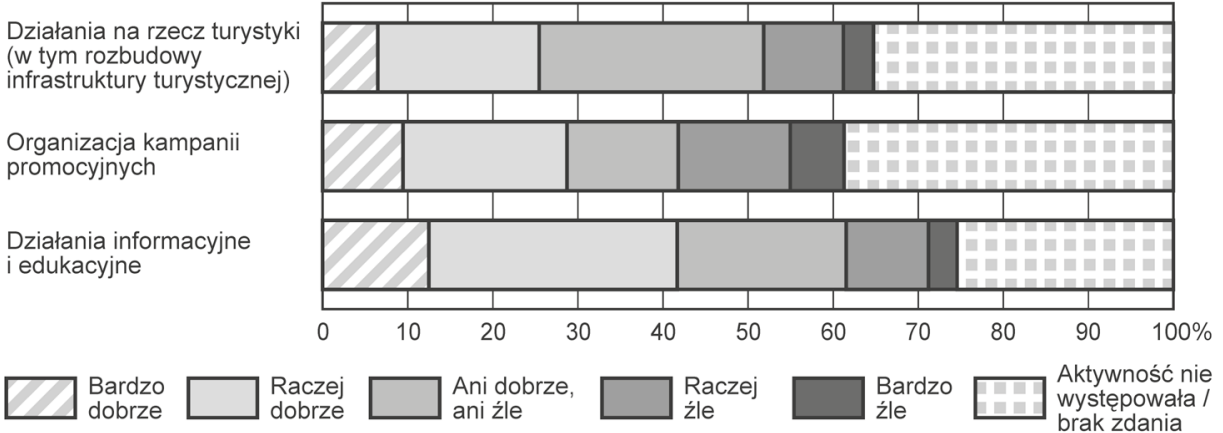

Rysunek 10. Ocena aktywności ZPKWM na terenie gmin Źródło: opracowanie własne na podstawie badań ankietowych

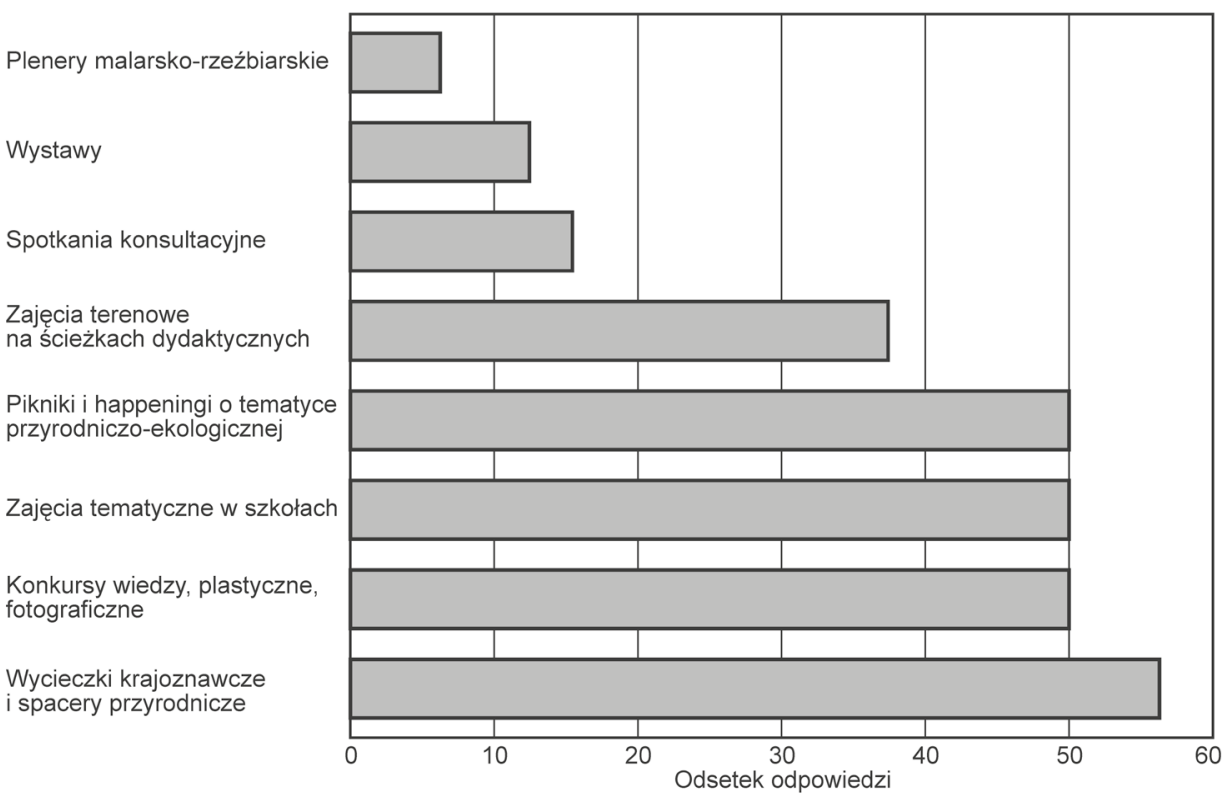

Rysunek 11. Działania edukacyjne ZPKWM uznane przez przedstawicieli gmin za najbardziej wartościowe i interesujące Źródło: opracowanie własne na podstawie badań ankietowych 
Opinie przedstawicieli miejscowych samorządów na temat działań edukacyjnych parków krajobrazowych, które przede wszystkim powinny być podejmowane, odpowiadały w dużej mierze preferencjom mieszkańców i turystów. Za najbardziej wartościowe i interesujące uznano bowiem wycieczki krajoznawcze i spacery przyrodnicze, pikniki i happeningi o tematyce przyrodniczej, a także konkursy i zajęcia tematyczne w szkołach (rys. 11).

\section{Podsumowanie}

Zespół Parków Krajobrazowych Województwa Małopolskiego prowadzi intensywną i różnorodną działalność edukacyjna, która jest ściśle związana z turystyką. Realizowane zajęcia edukacyjne kierowane są najczęściej do dzieci i młodzieży uczącej się. Dotychczas dominowały zajęcia stacjonarne, prowadzone głównie w szkołach. Zamierzeniem władz i pracowników Zespołu jest zwiększenie w przyszłości udziału zajęć w terenie, aby to obszary cenne przyrodniczo i krajobrazowo w granicach parków częściej stanowiły bezpośrednie miejsce zdobywania wiedzy i kształtowania świadomości przyrodniczej wśród młodych ludzi. ZPKWM dociera ze swoją ofertą zajęć edukacyjnych nie tylko do szkół w granicach parków krajobrazowych, ale również do innych placówek w województwie, w tym leżących na obszarach chronionego krajobrazu, które również podlegają Zespołowi. Oprócz dzieci i młodzieży szkolnej ZPKWM kieruje ofertę edukacyjną do szerokiego grona odbiorców w różnych grupach wiekowych, a zwłaszcza całych rodzin, studentów uczelni wyższych, przedstawicieli samorządów lokalnych i tych grup mieszkańców, których codzienna praca ma istotny wpływ na funkcjonowanie środowiska przyrodniczego. O zaangażowaniu ZPKWM na rzecz ciągłego polepszania oferty edukacyjnej i turystycznej świadczą inwestycje związane z budową nowych wielofunkcyjnych centrów edukacyjnych oraz z wytyczaniem kolejnych ścieżek dydaktycznych. Działalność edukacyjna Zespołu przejawia się również poprzez ofertę wydawnicza, rozwijanie serwisu internetowego wraz z Geoportalem oraz przez wykorzystanie nowoczesnych form komunikacji, takich jak media społecznościowe.

Pomimo podejmowanych działań w zakresie edukacji i turystyki ZPKWM pozostaje instytucją słabo rozpoznawalną $w$ społeczeństwie i dotyczy to zarówno mieszkańców parków krajobrazowych, jak i turystów przebywających w ich granicach. Niemniej jednak zdecydowana większość mieszkańców i turystów popiera funkcjonowanie parków krajobrazowych 
jako obszarowych form ochrony przyrody oraz dostrzega pozytywny ich wpływ na rozwój turystyki. Zdecydowana aprobata turystów dla funkcjonowania parków krajobrazowych niejednokrotnie nie wyklucza jednak braku świadomości przebywania na terenie parku krajobrazowego w trakcie uprawiania turystyki. Mieszkańcy terenów objętych ochroną w ramach parków krajobrazowych rzadko uczestniczą w wydarzeniach organizowanych przez Zespół i mają niewielką wiedzę na ich temat. Jednakże zarówno mieszkańcy, jak i turyści odwiedzający parki krajobrazowe uświadomieni na temat działalności ZPKWM wykazują wysokie zainteresowanie formami aktywności edukacyjnej i wyrażają chęć włączenia się w działania na rzecz parków. Chęć skorzystania z oferty edukacyjnej Zespołu deklarują najczęściej młodzi mieszkańcy parków, ankietowani z wyższym wykształceniem i uprawiający różne rodzaje aktywności turystyczno-rekreacyjnej, a wśród turystów - osoby w średnim wieku z wyższym wykształceniem. Działań na rzecz parków najchętniej podjęliby się natomiast młodzi ludzie legitymujący się wyższym wykształceniem. Przedstawiciele lokalnych władz również wykazują poparcie dla działalności ZPKWM, zdecydowanie wskazując na rozwój turystyki jako główną korzyść funkcjonowania parków krajobrazowych. Zawiązana dotychczas współpraca pomiędzy ZPKWM a gminami z parkami krajobrazowymi $w$ ich granicach jest pozytywnie oceniana przez lokalne władze.

\section{Bibliografia}

Adamczewska, M. (2008). Rola obszarów przyrodniczo cennych w edukacji geograficznej na przykładzie województwa łódzkiego. W: R. Wiśniewski, W. Gierańczyk (red.), Geografia we wspótczesnym systemie kształcenia. Dokumentacja Geograficzna 38 (s. 18-23). Warszawa: Instytut Geografii i Przestrzennego Zagospodarowania PAN.

Badanie świadomości przyrodniczej i postaw osób, podmiotów i instytucji związanych z małopolskimi parkami krajobrazowymi (2019). Pobrane z: https://www.obserwatorium.malopolska.pl/wp-content/uploads/2020/03/Raport_Badanie_Swiadomosci_Przyrodniczej.pdf (9.12.2020).

Chojnacka-Ożga, L., Ożga, W., Rutkiewicz, A. (2013). Działania Mazowieckiego Zespołu Parków Krajobrazowych na rzecz edukacji i rekreacji. Studia i Materiały Centrum Edukacji Przyrodniczo-Leśnej w Rogowie, 15 (34), 216-222.

Fritzkowski, S. (2020). Z działalności Zespołu Parków Krajobrazowych Województwa Wielkopolskiego (1 stycznia-31 grudnia 2019). Biuletyn Parków Krajobrazowych Wielkopolski, 27 (29), 98-103.

Generalna Dyrekcja Ochrony Środowiska (2020). Pobrane z: http://www.gdos.gov.pl/ dane-i-metadane (9.12.2020). 
Geoportal Zespołu Parków Krajobrazowych Województwa Małopolskiego (2020). Pobrane z: http://zpkwm.netgis.pl/ (21.12.2020).

Główny Urząd Geodezji i Kartografii (2020). Pobrane z: http://www.gugik.gov.pl/pzgik/ dane-bez-oplat/dane-z-panstwowego-rejestru-granic-i-powierzchni-jednostek-podzialow-terytorialnych-kraju-prg (9.12.2020).

Kruk, H. (2014). Działalność parków krajobrazowych w opinii pracowników gmin województwa wielkopolskiego - wyniki badań. Studia i Prace Wydziału Nauk Ekonomicznych w Zarządzania, 37 (3), 223-233.

Łakomiec, J. (2002). Edukacja ekologiczna w parkach krajobrazowych - współpraca z gminami w Wielkopolsce. Przeglad Komunalny, 12, 46-47.

Ochrona środowiska 2019 (2019). Analizy statystyczne GUS. Pobrane z: https://stat.gov.pl/ obszary-tematyczne/srodowisko-energia/srodowisko/ochrona-srodowiska-2019,1,20. html (9.12.2020).

OpenStreetMap (2020). Pobrane z: https://download.geofabrik.de/europe/poland.html (9.12.2020).

Radecki, W. (2008). Prawne bariery funkcjonowania parków krajobrazowych. W: K. Zimniewicz (red.), Bariery w zarządzaniu parkami krajobrazowymi w Polsce. Warszawa: Polskie Wydawnictwo Ekonomiczne.

Radecki, W. (2016). Parki krajobrazowe i obszary chronionego krajobrazu w prawie polskim czeskim i słowackim. Biuletyn Parków Krajobrazowych Wielkopolski, 22 (24), 16-33.

Referowska-Chodak, E. (2018). Współpraca edukacyjna nadleśnictw Lasów Państwowych z perspektywy parków krajobrazowych. Sylwan, 162 (09), 775-784.

Regulamin organizacyjny Zespołu Parków Krajobrazowych Województwa Małopolskiego (2018). Pobrane z: https://bip.malopolska.pl/zpkwmalopolskiego,m,4225,regulamin-organizacyjny.html (21.12.2020).

Rękas, A. (2004). Parki krajobrazowe województwa śląskiego jako czynnik rozwoju turystyki oraz element ochrony krajobrazu kulturowego. W: M. Strzyż (red.), Perspektywy rozwoju regionu w świetle badań krajobrazowych. Problemy Ekologii Krajobrazu 12 (s. 187-200). Kielce: Instytut Geografii Akademii Świętokrzyskiej.

Schubert, T. (2008). Park krajobrazowy - zaniedbana idea ochrony przyrody i krajobrazu. W: K. Zimniewicz (red.), Bariery w zarządzaniu parkami krajobrazowymi w Polsce. Warszawa: Polskie Wydawnictwo Ekonomiczne.

Stachyrak, J. (1998). Formy edukacji ekologicznej w Zespole Karpackich Parków Krajobrazowych w Krośnie. Parki Narodowe, 1, 28-29.

Statut Zespołu Parków Krajobrazowych Województwa Małopolskiego w Krakowie. Załącznik do uchwały NrXVI/227/15 Sejmiku Województwa Małopolskiego z dnia 23 listopada 2015 r.

Ustawa z dnia 16 kwietnia 2004 r. o ochronie przyrody. DzU 2004, nr 92, poz. 880.

Zawilińska, B. (2007). Turystyka w działalności parków krajobrazowych w Karpatach. W: W. Kurek, R. Faracik (red.), Studia nad turystyka. Prace geograficzne i regionalne. Kraków: Instytut Geografii i Gospodarki Przestrzennej Uniwersytetu Jagiellońskiego.

Zawilińska, B. (2010). Możliwości rozwoju turystyki w parkach krajobrazowych Karpat Polskich w świetle idei zrównoważonego rozwoju. Kraków: Uniwersytet Ekonomiczny w Krakowie.

Zawilińska, B., Hołuj, A. (2014). Impact of protected areas on the development of suburban areas: The case of Kraków metropolitan area. European Spatial Research and Policy, 21 (1/2014), 137-155. https://doi.org/10.2478/esrp-2014-0010

Zimniewicz, K. (2005). Zarządzanie polskimi parkami krajobrazowymi. Próba diagnozy. Poznań: Wydawnictwo Akademii Ekonomicznej w Poznaniu.

ZPKWM (2020). Pobrane z: https://zpkwm.pl/ (21.12.2020). 
Wojciechowski, K.T. (2018). Edukacja ekologiczna w Zespole Lubelskich Parków Krajobrazowych - zakres, formy, metody. W: Проблеми екологіï та еволюиїі екосистем в умовах трансформованого середовищ а (tłum. Problemy ekologii i ewolucji ekosystemów w warunkach przekształconego środowiska) (s. 309-314). Чернігів: Десна Поліграф.

\title{
DZIAŁALNOŚĆ ZESPOŁU PARKÓW KRAJOBRAZOWYCH WOJEWÓDZTWA MAŁOPOLSKIEGO \\ W ZAKRESIE EDUKACJI I ROZWOJU TURYSTYKI
}

\begin{abstract}
Abstrakt: W artykule dokonano analizy działalności Zespołu Parków Krajobrazowych Województwa Małopolskiego (ZPKWM) w zakresie edukacji i rozwoju turystyki. Część empiryczna składa się z analizy działań podejmowanych przez Zespół, opracowanej na podstawie materiałów pozyskanych w dyrekcji Zespołu oraz wywiadów z pracownikami, a także prezentacji opinii mieszkańców, turystów i lokalnych władz dotyczących tej działalności, zgromadzonych w wyniku badań ankietowych. Parki krajobrazowe prowadzą ożywioną działalność edukacyjną która jest ściśle związana z aktywnością z zakresu rozwoju turystyki. W szczególności realizują zajęcia tematyczne, głównie w szkołach oraz w terenie, prowadzą ośrodki i ścieżki dydaktyczne, serwisy internetowe i działalność wydawniczą. Funkcjonowanie parków jest popierane przez mieszkańców i turystów, choć jako instytucja są one mało znane. Deklarowane wysokie zainteresowanie udziałem w inicjatywach edukacyjnych (zwłaszcza wycieczkach) oraz poparcie ze strony lokalnych samorządów stwarzają dogodne warunki dla rozwoju analizowanych form działania Zespołu.
\end{abstract}

Słowa kluczowe: park krajobrazowy, województwo małopolskie, edukacja ekologiczna, turystyka.

\section{EDUCATIONAL ACTIVITY AND TOURISM DEVELOPMENT IN THE LANDSCAPE PARKS OF MAŁOPOLSKA VOIVODESHIP}

Summary: The article analyzes activity in the landscape parks of Małopolska Voivodeship in terms of education and tourism development. The empirical part of the article consists of two components: (1) analysis of the activities undertaken by the landscape parks, carried out on the basis of materials obtained from their joint management and interviews with its employees; (2) presentation of residents', tourists' and local authorities' opinions on these activities collected through questionnaire surveys. Landscape parks conduct educational activity which is closely related to activities in the field of tourism development. These include conducting thematic classes - mainly taking place in schools and less often in the field, maintaining educational centers, educational trails and websites, as well as publishing materials. The functioning of landcape parks is supported both by local residents and tourists, although the parks as an institution are only poorly recognized. The high declared interest in participating in educational initiatives (especially in tours) and the support for local governments create favorable conditions for the development of Małopolska Voivodeship's landscape park activity..

Keywords: landscape park, Małopolska Voivodeship, ecological education, tourism. 